\title{
Biodiversity Of Macroalgae Endhophytic Microorganisms and It's Potential As An Antibacteria Againts Eschericia coli On West Beach Pasir Putih Pangandaran, West Java
}

\author{
Nia rossiana ${ }^{1}$, Ida indrawati ${ }^{1}$, Sri Rejeki Rahayuningsih ${ }^{2}$, \\ Idzni Harashta Haifa ${ }^{3}$, Betty Mayawatie ${ }^{4}$ \\ \{niarossiana@yahoo.com¹, ida.indrawati81@gmail.com², rahayuningsih.sr@gmail.com³, \\ idzniharashita@gmail.com ${ }^{4}$, mayawatiebetty@gmail.com ${ }^{5}$ \}
}

\begin{abstract}
${ }^{1}$ Department of Biology, Faculty of Mathematics and Natural Sciences, Padjadjaran University.,Jalan Raya Bandung-Sumedang Km 21, Jatinangor Sumedang 45363, West Java Indonesia. Tel. fax +62-284$288828^{1,2,3,4,5}$
\end{abstract}

\begin{abstract}
Macroalgae that found in Pantai Barat Pasir Putih Pananjung Pangandaran, West Java is quite diverse. The three main classes of macroalgae are Clorophyceae, Rhodophyceae, and Paeophyceae found there. Five species including Ulva fasciata, Gelidiella acerosa, Halimeda sp., Turbinaria sp., and Chaetomorpha sp. representing the three main classes. Currently, marine endophytic is an interesting new source for its potential. This research was conducted to find out various endophytic microorganisms (endophytic bacteria and endophytic microfungi) that live in macroalgae's tissue through the direct seed planting method on agar medium and their potential as antibacterial against Escherichia coli. The endophytic microorganisms obtained were purified through gram staining on bacterial isolates and moist chamber for microfungi isolates to be further identified under the microscope. Endophytic bacteria obtained as many as 17 pure isolates consisting of gram positive and negative bacillus and cocci bacteria, whereas five endophytic microfungi obtained from these macroalgae were obtained by five genera suspected of Paecilomyces sp., Mycelia sterilia, Geomyces sp., Penicillium sp., and Cladosporium sp. The endophytic bacteria isolates obtained were tested for their antibacterial activity against $E$. coli. The results obtained showed that there was an average of the largest inhibition zones with sensitive categories of macroalgae Halimeda sp. that is equal to $10.33 \mathrm{~mm}$.
\end{abstract}

Key words: Antibacterial Activity, Chaetomorpha sp., Endophytic Microorganism, Gelidiella acerosa, Halimeda sp., Macroalgae, Turbinaria sp., Ulva fasciata

\section{Introduction}

One of the low-level flora that lives in the coastal area is macroalgae. Macroalgae are marine flora that can grow in shallow and intertidal seabed[1] Macroalgae generally grow attached to certain substrates such as corals, mud, sand, rocks and other hard objects[2]. Indonesia is famous for its tropical climate which makes it easy for macroalgae species to grow and live along sea travel. Naturally the spread of macroalgae is scattered throughout the 
clear area, usually a ship that is rocky and which has a limestone foundation, namely in the intertidal area or areas that have tides. Even Indonesia has the top position in the row of macroalgae producers in the world. Some macroalgaes in Indonesia are beneficial because of their unique and special potential to be developed. Until now there are many more macroalgae that have not been identified and are known for their potential.

Recent estimations show that the planet contains around 300,000 plant species, most of which contain endophytes[3]. When endophytic microorganisms are observed, we can know their role in the plant tissue that is boarded. Because of this role, the attention of endophytic microorganisms continues to increase in the past few years because these endophytic microorganisms have several important functions such as extracting plant nutrients, helping / increasing growth and also plant vigor and potentially providing resistance to host plants to fight pathogenic infections. And as a source of secondary metabolites. Marine endophytes are very attractive as new and rich sources of biologically active products. They live in close association with soft-bodied marine plants, which do not have a clear structural defense mechanism, and thus rely on chemical defense by the production of bioactive secondary metabolites, either by themselves or by related microflora, to survive in their extreme habitats[4]. Endophytic microorganisms have great potential in finding new sources of medicine. Macroalgae is a natural source that has the potential to produce secondary metabolites that produce abundant bioactive compounds in Indonesian merine, making it a great opportunity for new drugs. Several studies have shown that besides being a producer of antibiotics, endophytic microbes are also capable of being anticancer[5], antihypertensive and antimalarial. In line with the statement[6] that endophytes have biological activities for treatment such as anticancer, immunomodulators, and anti-inflammation. In addition, microorganisms have advantages compared to other organisms such as easy to develop and multiply, relatively short life cycles, produce large amounts of bioactive compounds, and are easy to find because they are abundant in nature. Marine endophytic microorganisms consist of bacteria and microfungi, most of them are attached and live on soft marine plant bodies. Marine endophytic bacteria contain chemical compounds from secondary metabolites that have the opportunity to be used as raw materials for new drugs, nutritional supplements, cosmetics, agrochemicals, and chemical probes from enzymes. The role of endophytic bacteria in enhancing plant growth is also supported by its ability to dissolve nutrients, tether nitrogen in the air, produce plant growth hormones, and control plants from disease attacks[7]. The reciprocal relationship between endophytic microfungi and hosts can activate the genesilencing mechanism or gene dam immersion followed by activation of specific biosynthesis which results in the structure of functional secondary metabolites. Macroalgae is a potential source of marine microfungi, this is because macroalgae are able to adapt to high salinity levels, nutrient limitations, low light exposure, or lack of oxygen which triggers endophytic pressure to produce bioactive compounds secondary metabolites as host plant defense mechanisms[8].

The main objective of this study was to determine the various endophytic microorganisms (endophytic bacteria and endophytic microfungi) that live in macroalgae through the direct seed planting method on agar medium and their potential as antibacterial against Escherichia coli. 


\section{Materials And Methods}

\subsection{Study area}

Materials and Methods should emphasize on the procedures and data analysis. For field study, it is better if study site is included (Figure 1).

\subsection{Location}

The location of research was done on Pantai Pasir Putih Pangandaran,West Java (Figure $1)$.

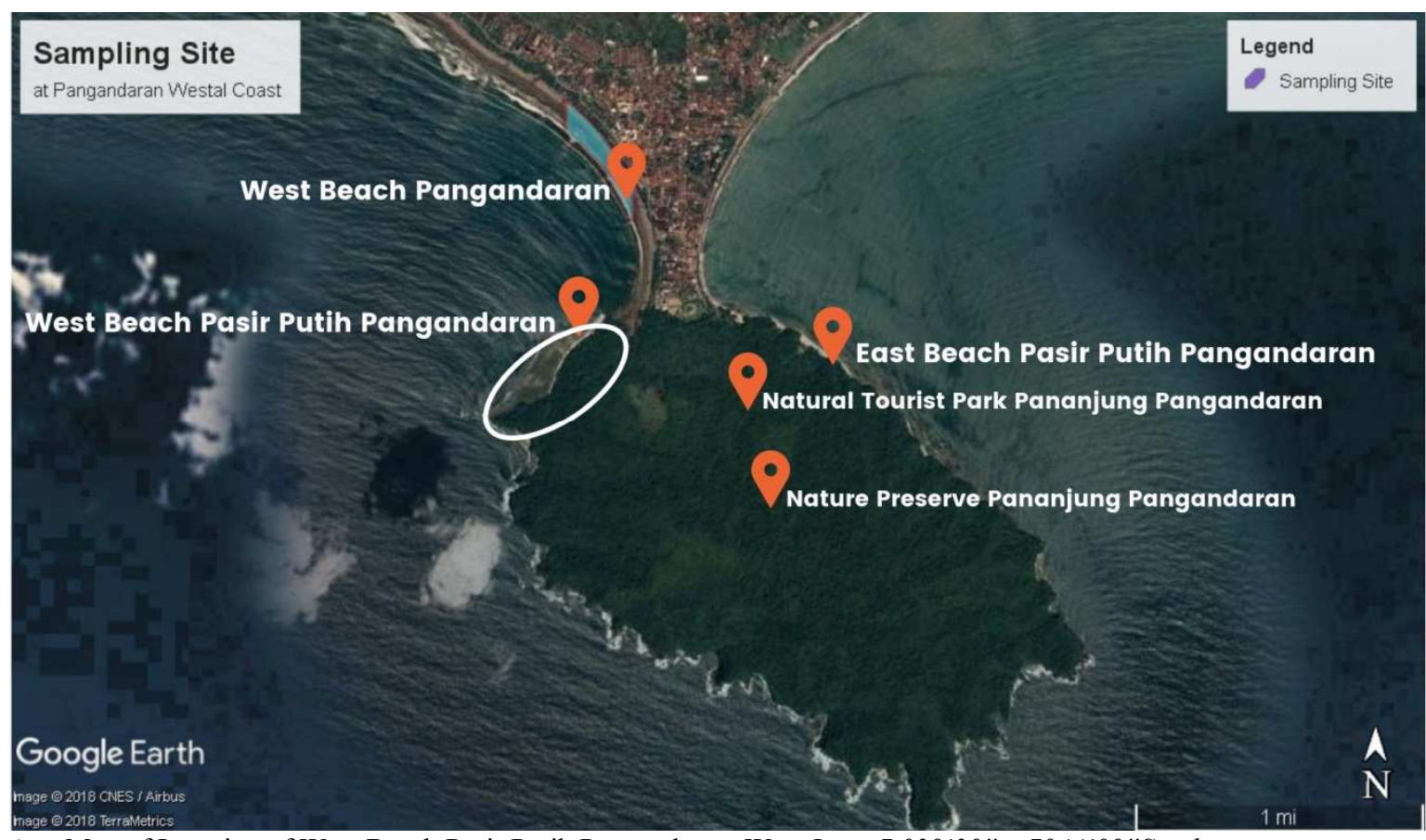

Fig.1 Map of Location of West Beach Pasir Putih Pangandaran, West Java. 7 039'30”- 7044'00”'South Latitude and 108035'00" - 108042'00" East Longitude. source: www.googleearth.com

\subsection{Materials}

The materials used are $1000 \mathrm{ml}$ erlenmeyer flask, alcohol 70\%, alcohol, $96 \%$ aluminum foil, analytic balance, aquades, autoclave, bacterial and beaker glass, Bunsen, carbol violet, chloramphenicol, coloring tray, cool box, cotton, discs, drop pipettes, filter paper,fucshin water, fungal incubator,glass objects, gloves, spirtus, heater,hygrometer, immersion oil, ketocenazole, labels, lugol,lux meters, macroalgae identification sheets, macroalgae sampels,magnetic stirers, microscopes, NA powder and PDA, petri dish, pH meter, plastic wrap , raffia , refractometers, round ose, scissors, seawater, spatulas, plugs, spray bottle, 
stakes, thermometers, stirring rod, stopwatches, streptomycin, test tube racks, tide tables, tweezers, UC bottle, vaseline,wooden clamp, ziplock plastic.

\subsection{Methods}

The method used in this research is roaming method and descriptive method. The roaming method was carried out for macroalgae inventory in the West Coast area of Pasir Putih, Pananjung Pangandaran. Descriptive method was carried out to obtain and identify various macroalgae endophytic microorganisms obtained and the antibacterial activity of endophytic microorganisms to Escherichia coli.

\subsection{Procedures}

\subsubsection{Laboratory Preparation}

Laboratory preparations are making medium NA (Nutrient Agar) and PDA (Potato Dextrose Agar) and sterilizing work equipment and medium on autoclaves at a temperature of $121^{\circ} \mathrm{C} 1 \mathrm{~atm}$ pressure.

\subsubsection{Macroalgae Sampling}

Macroalgae sampling on West Java White's sand Coast of Pananjung Pangandaran Beach was carried out during low tide conditions, according to, which stated that macroalgae grows or not. Then the macroalgae is taken from all parts of the thallus intact using latex gloves. Then, the macroalgae obtained was inserted into the plastic sample and put in a cool box.

\subsubsection{Isolation of Endophytic Macroalgae Microorganisms}

Isolation of endophytic microorganisms is carried out by direct seed planting according to[9]. All thallus macroalgae are rinsed with sterile seawater, soaked in distilled water and in $70 \%$ alcohol. Then, macroalgae intact thallus is cut into 8 small parts using sterile scissors. Pieces of macroalgae is implanted into the NA medium and the PDA uses the direct seed planting method on the four equal parts of the petri dish. After that, petri dishes were incubated in at $37^{\circ} \mathrm{C}$ for 24 hours for bacteria and at room temperature for $48-72$ hours for microfungi.

\subsubsection{Identification of Endophytic Bacteria}

Identification of endophytic bacteria was carried out using gram staining to group bacteria based on the structure of cell walls into gram-positive bacteria and gram-negative bacteria. Gram-positive bacteria will appear purple and gram-negative bacteria will appear red.

\subsubsection{Identification of Endophytic Microfungi}

Identification of endophytic microfungi was carried out with two observations, namely macroscopic observation and microscopic observation. Macroscopic observations include 
colony color, colony shape, elevation, margin, and size of colonies. Meanwhile, microscopic observations were carried out using the Moist Chamber technique and a comparison of the literature referring to[10] with the title "Pictoral Atlas of Soil And Seed Fungi Morphologies Of Cultured Fungi And Key Species".

\subsubsection{Bacterial Suspension}

The making of bacterial suspension test was carried out by homogenizing Escherichia coli with physiological $\mathrm{NaCl} 0.9 \%$ sterile. Turbidity used in the antibacterial activity test was equated with McFarland 0.5 ( $9 \times 10^{8}$ cells / $\mathrm{mL}$ sample).

\subsubsection{Antibacterial Activity Testing}

Antibacterial activity was carried out by the disc (Kirby Bauer) method on endophytic bacteria isolated from various macroalgae against E. coli. The parameters observed were the diameter of the inhibition zone / clear zone formed around the disc. The diameter of the inhibitory zone formed was measured and grouped in sensitive groups very strong, sensitive, semi-sensitive and resistant referring to[11] as in table 1 :

Table 1. Category of Growth inhibition zones antibacterial activity

\begin{tabular}{cl}
\hline \multicolumn{1}{c}{ Growth inhibition zones } & \multicolumn{1}{c}{ Category } \\
$>20 \mathrm{~mm}$ & Strong \\
$10-20 \mathrm{~mm}$ & Sensitive \\
$5-10 \mathrm{~mm}$ & Less sensitive \\
$<5 \mathrm{~mm}$ & Resistant \\
\hline \multicolumn{2}{c}{ Source: (Davis dan Stout, 1971) }
\end{tabular}

\subsection{Data analysis}

Data analysis was carried out descriptively based on the macroalgae biodiversity data on the West Coast of Pananjung Pangandaran White Sand and macroalgae endophytic microorganisms, and the antibacterial activity of endophytes against $E$. coli

\section{Results And Discussion}

Results and Discussion should be written as a series of connecting sentences, however, for manuscript with long discussion should be divided into subtitles. Results should be clear and concise.

\subsection{Result-1}

Community macroalgae are found on the West Beach Pasir Putih Pananjung Pangandaran has considerable diversity. Intertidal zone on the West Coast White Sand has a substrate in the form of dead coral and rocks. This allows many macroalgae grow there, because it indicates that the flow or movement of sea water big and good. macroalgaeobtained from the West Coast White Sand Pananjung Pangandaran, in Events during low tide at 16:30 
pm with the condition of seawater $\mathrm{pH} 8.1,63 \%$ humidity levels, light intensity of $5.83 \times 100$ lux, $35.6 \%$ salinity, and temperature water $39^{\circ} \mathrm{C}$ are summarized in table 2

Table 1 Physical and Chemical Conditions of West Beach Pasir Putih Pangandaran, West Java

\begin{tabular}{llllc}
\hline $\mathrm{pH}$ & Humidity & Light intensity & Salinity & The water temperature \\
8.1 & $63 \%$ & $5,83 \times 100 \mathrm{lux}$ & $35.6 \% \mathrm{o}$ & $39{ }^{\circ} \mathrm{C}$ \\
\hline
\end{tabular}

Acerosa Gelidiella macroalgae, Ulva fasciata, Halimeda sp., Turbinaria sp., and Chaetomorpha sp. a few macroalgae obtained at Pasir Putih Barat, Pangandaran, West Java. Gelidiela acerose has the characteristics of a relatively small size, red-brown colored thallus, thallus stems grow upright with pinnate branching as forming tiny barbs.

Ulva fasciata is one of the most common green algae and happens almost every season on the Indian coast ${ }^{[14]}$, or sea lettuce Ulva (sea lettuce) is a seaweed belonging to Chlorophyta division because cells contain many contain chlorophyll that gives green. Thallus morphology is in the form of thin, flattened like a sword consisting of two layers of cells.Halimeda sp. having the green colored thallus with Holdfast discoidal type, thallus on macroalgae have a shape such as a coin, branched, growing in a clump. The outside of the cube-shaped cell network and meeting, part of the cortex cells slightly rounded shape then the medulla part cylindrical cells are located irregularly.

Results Isolation of Endophytic Bacteria red macroalgae (Gelidiella acerosa), Green (Ulva fasciata, Halimeda sp., and Chaetomorpha sp.), And Brown (Turbinaria sp.)

Macroalgae endophytic bacteria red, green, or brown isolated from several colonies that grow around thallus grown on NA medium. Endophytic bacterial colonies that grow around macroalgae differentiated according to form colonies, elevation, or margins or edges and be purified. Results purification identified microscopically through Gram stain. The endophytic bacteria macroalgae Gelidiella acerosa gained 3 pure isolates of endophytic bacteria. Based on the results of gram staining gram-positive bacillus bacteria identified are suspected as Bacillus sp., Other than that obtained cocci gram negative bacteria and bacteria bacillus gram on other isolates.

The endophytic bacteria macroalgae Ulva fasciata identified by observation through gram stain acquired 4 pieces of pure isolates, namely Bacillus sp.1, Bacillus sp.2, Bacillus sp.3 and Bacillus sp.4. All isolates were observed microscopically has the same shape (rod) but the size is different.

Endophytic bacteria isolated from macroalgae Halimeda sp. consists of three isolates of bacteria isolated from three different colonies around thallus Halimeda sp. Endophytic bacteria isolated Halimeda sp. obtained 3 isolates comprising 1 isolate gram positive and 2 isolate gram negative. Endophytic bacteria isolated macroalgae Turbinaria sp. consist of 3 pure isolates suspected of Bacillus sp gram-positive and 2 isolates gram positive cocci shaped and gram negative.

Results of Isolation of Microfungi Endophytes of Red Macroalgae (Gelidiella acerosa), Green (Ulva fasciata), and Chocolate (Halimeda sp. And Turbinaria sp.)

Endophytic microfungi isolated from various macroalgae grown on PDA media with the direct seed planting method in the form of several colonies around macroalgae and differentiated according to hyphae color, elevation, margin, shape and size. The pure isolates obtained were identified using the Moist Chamber method. Based on the results of the 
acquisition of the microalgae isolates of the macroalgae Gelidiella acerosa, there were 3 different microfungi colonies. and the results of the identification of microfungi were suspected as Penicillium sp1, Mycelia sterilia, and Penicillium sp2.

Endophytic microfungi isolated from macroalgae Ulva fasciata were obtained from various different colonies around the macroalgae thallus. There are 3 pure microfungi isolates obtained which are thought to be Paecilomyces sp., Mycelia sterilia, and Geomyces pannorum. Endophytic microfungi isolated from the Halimeda sp. Macroalgae. which was identified, namely 1 pure isolate which showed that the genera of microfungi through macroscopic observation (direct observation) and microscopically with the Moist Chamber technique, Penicillium.

There is 1 pure isolate of macroalgae endophytic Turbinaria sp. suspected as Cladosporium sp. based on the results of macroscopic observations on colonies and microscopic observations through the Moist Chamber technique. Morphological characteristics of bacteria and endophytic microfungi of various macroalgae are shown in table 3 below:

Table 3. Microfungi Endophytic Bacteria which Isolated from macroalgae (Ulva fasciata, Gelidiella acerosa, Halimeda sp., Turbinaria sp.)

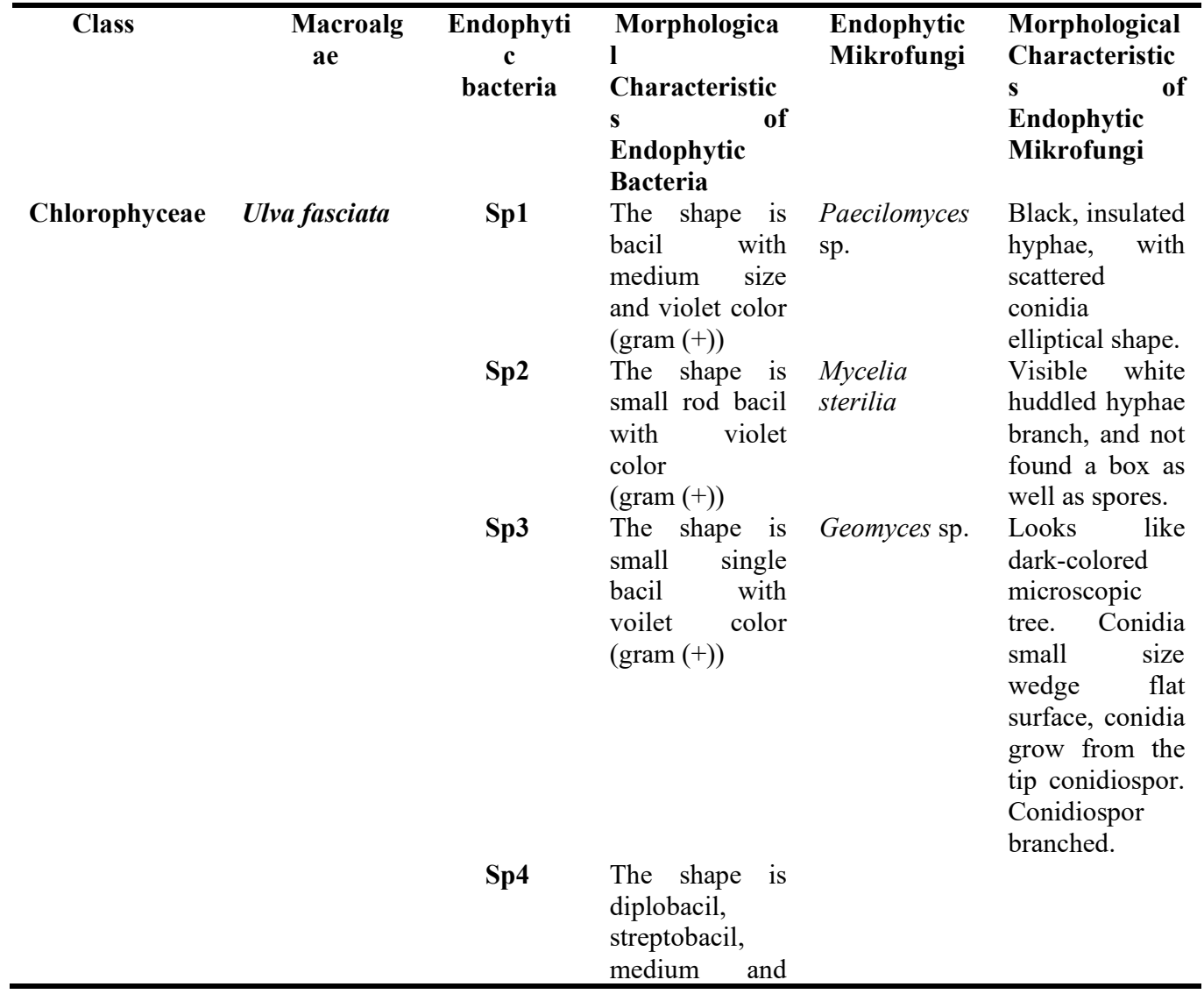




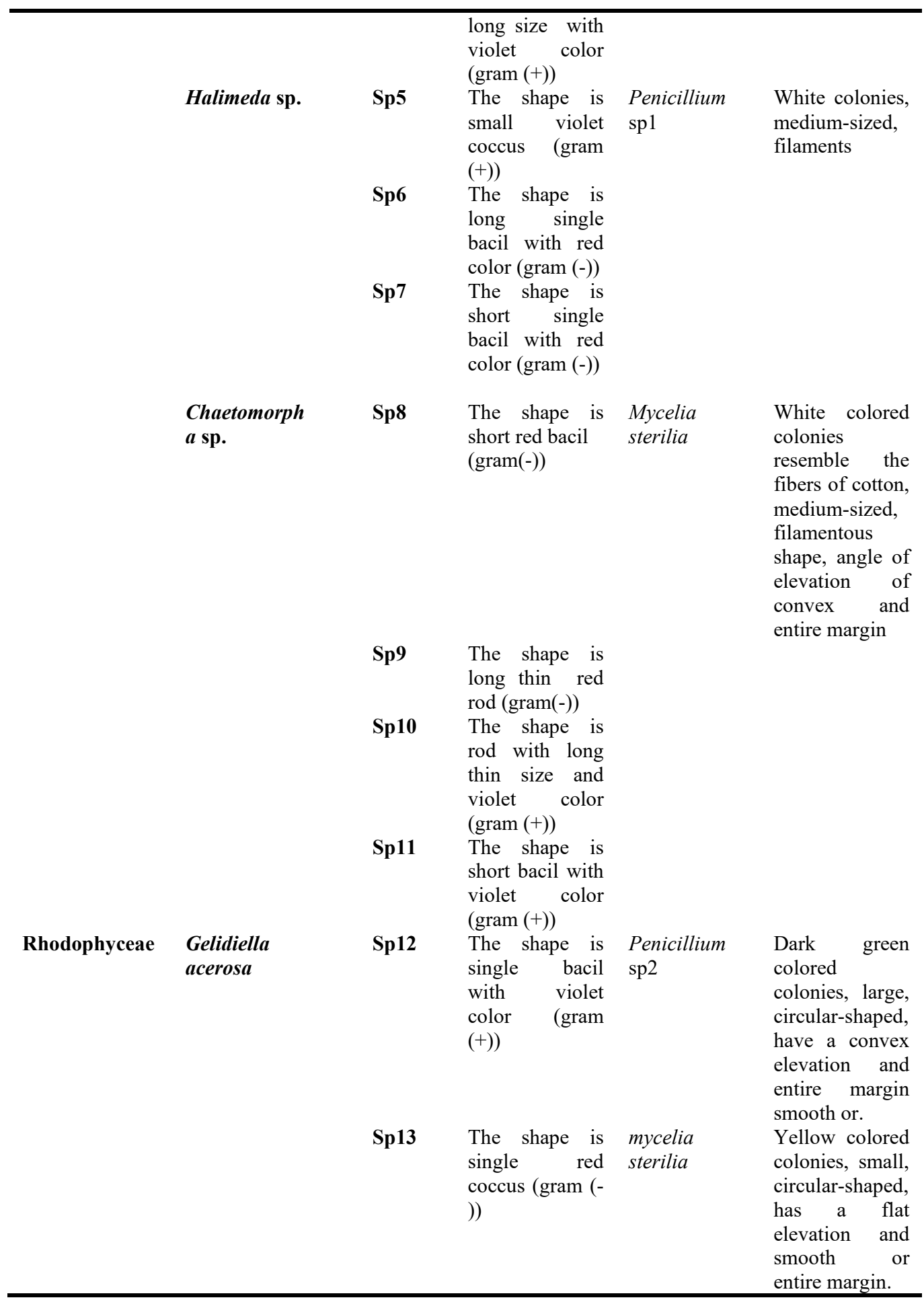




\begin{tabular}{|c|c|c|c|c|c|}
\hline \multirow{4}{*}{$\begin{array}{l}\text { Phaepophycea } \\
\text { e }\end{array}$} & \multirow{4}{*}{ Turbinaria sp. } & Sp14 & $\begin{array}{l}\text { The shape is } \\
\text { red single bacil } \\
\text { smaller than } \\
\text { Sp.5 (gram }(-) \text { ) }\end{array}$ & $\begin{array}{l}\text { Penicillium } \\
\text { sp1 }\end{array}$ & \multirow{4}{*}{$\begin{array}{l}\text { Colonies } \\
\text { colored white, } \\
\text { large, } \\
\text { filamentous } \\
\text { shape, elevation } \\
\text { umbonate, and } \\
\text { margins lobate } \\
\text { Colonies of } \\
\text { black color. }\end{array}$} \\
\hline & & Sp15 & $\begin{array}{l}\text { The shape is } \\
\text { bacil with } \\
\text { moderate size } \\
\text { and violet color } \\
(\operatorname{gram}(+))\end{array}$ & $\begin{array}{l}\text { Cladosporiu } \\
m \text { sp. }\end{array}$ & \\
\hline & & Sp16 & $\begin{array}{l}\text { The shape is } \\
\text { single violet } \\
\text { coccus(gram } \\
(+) \text { ) }\end{array}$ & & \\
\hline & & Sp17 & $\begin{array}{l}\text { The shape is } \\
\text { single red } \\
\text { coccus (gram (- } \\
\text { )) }\end{array}$ & & \\
\hline
\end{tabular}
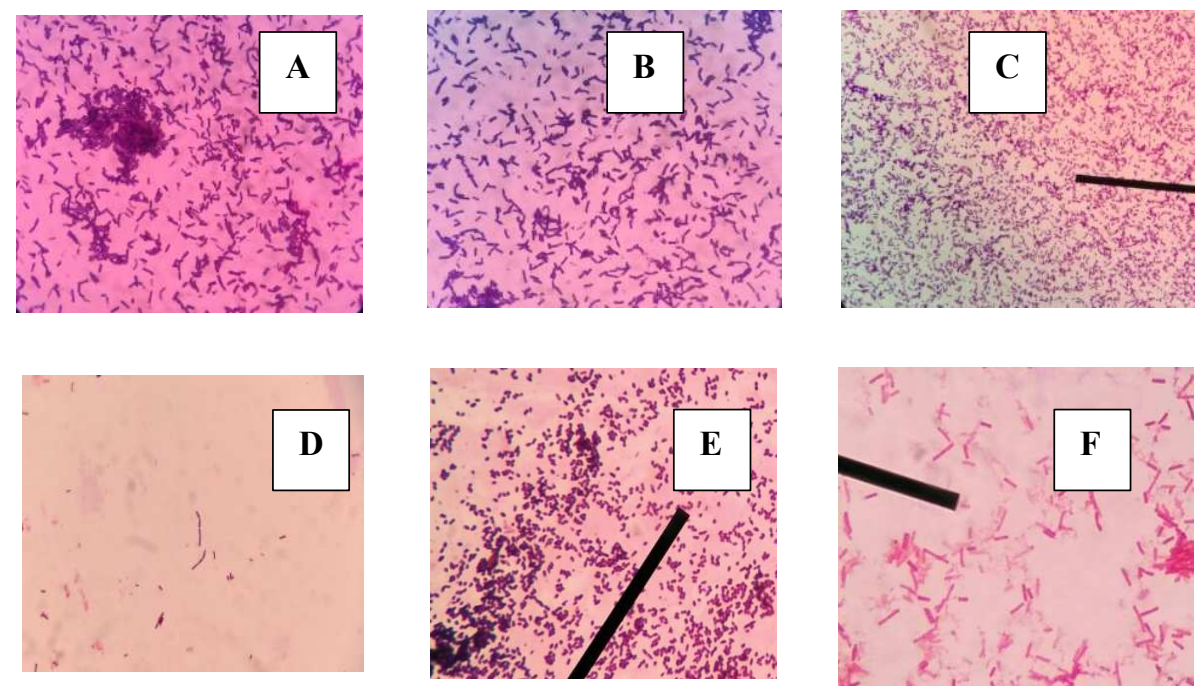

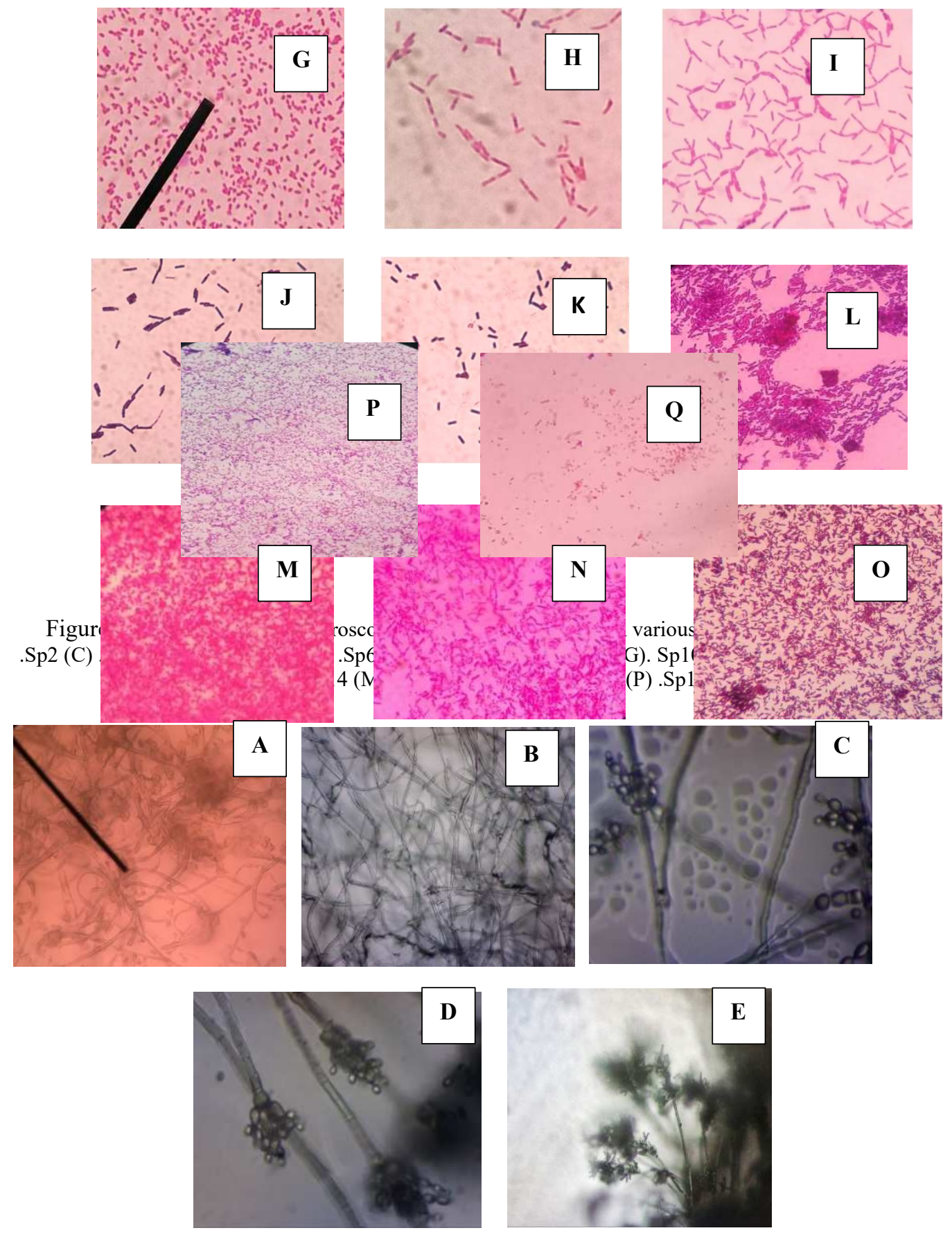

Fig. 3 Endophytic microfungi from different types of macroalgae (A).Paecylomices sp. (B). Mycelia sterilia 


\section{(C). Geomyces sp. (D). Penicillium sp. (E). Cladosporium sp.}

\section{Antibacterial activity of macroalgae}

The antibacterial activity of macroalgae Gelidiella acerosa, Chaetomorpha sp., Halimeda sp., And Turbinaria sp. are shown in Table 4 as follows:

Table 4. Antibacterial Activities of Endophytic Bacteria macroalgae

\begin{tabular}{|c|c|c|c|c|c|c|}
\hline \multirow[t]{2}{*}{ Species Macroalgae } & \multirow[t]{2}{*}{$\begin{array}{l}\text { Endophytic } \\
\text { bacteria }\end{array}$} & \multicolumn{3}{|c|}{$\begin{array}{l}\text { Growth inhibition zones } \\
(\mathrm{Mm})\end{array}$} & \multirow[t]{2}{*}{$\bar{x}$} & \multirow[t]{2}{*}{ Category } \\
\hline & & 1 & 2 & 3 & & \\
\hline \multirow[t]{2}{*}{ Gelidiella Aceros } & sp.1 & 10 & 6 & 6 & 7.3 & LS \\
\hline & sp.2 & 6 & 6 & 8 & 6.7 & LS \\
\hline \multirow[t]{2}{*}{ Chaetomorpha sp. } & sp. 1 & 9 & 10 & 9 & 9.3 & LS \\
\hline & sp. 2 & 6 & 6 & 7 & 6.3 & LS \\
\hline \multirow[t]{2}{*}{ Halimeda sp. } & sp. 1 & 11 & 10 & 10 & 10.33 & $\mathrm{~S}$ \\
\hline & sp.2 & 10 & 11 & 9.5 & 10,16 & S \\
\hline Turbinaria sp. & sp.1 & 9 & 10 & 10 & 9.7 & LS \\
\hline
\end{tabular}

Notes: VS : Very sensitive, S: Sensitive, LS : Less Sensitive, R: resistance

Results of testing the antibacterial activity of endophytic bacteria macroalgae according diameter clear zone formed around the disc drive is shown in Figure 5 as follows:
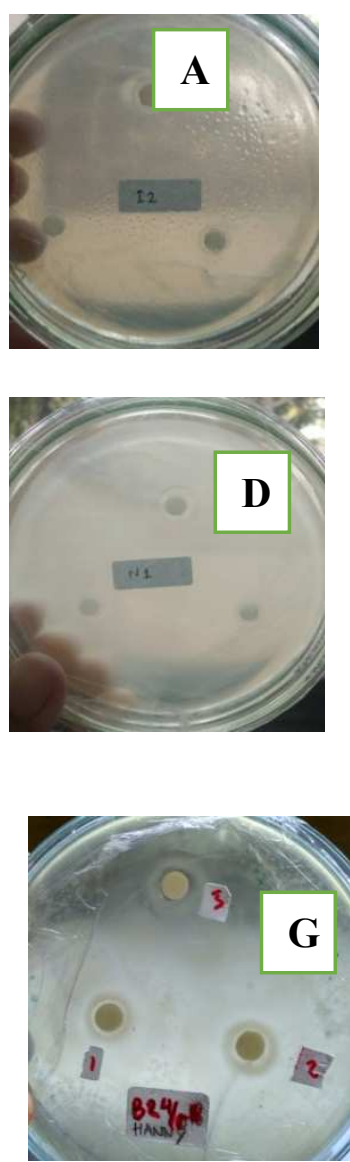
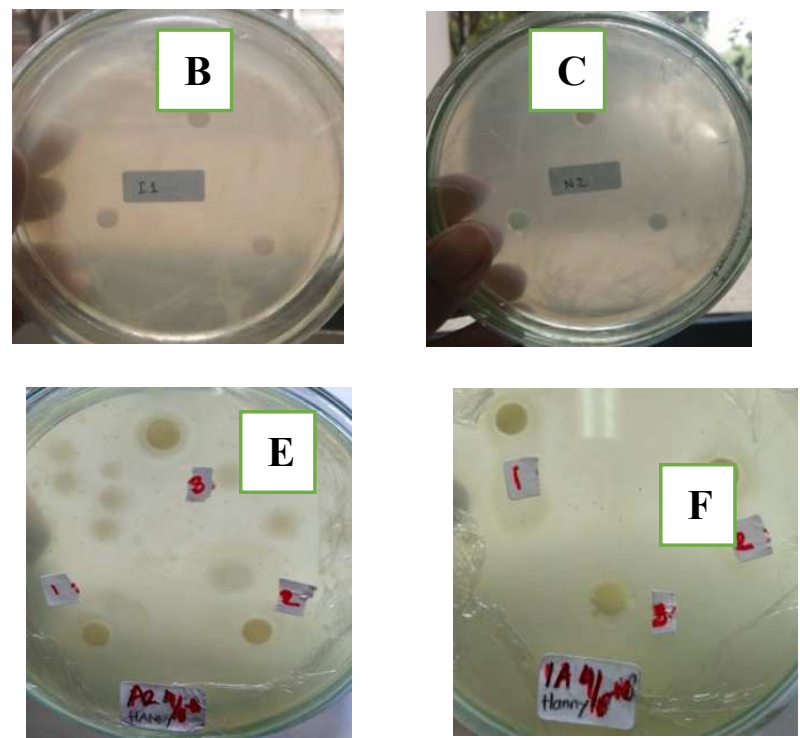
Fig. 4 Endophytic Bacteria Inhibition zone (A) .Gelidiella acerosa sp.1 (B). G. acerosa sp.2 (C). Chaetomorpha $s p . s p .1(D)$. Chaetomorpha sp. $s p .2(E)$. Halimeda $s p . s p .1(F)$ Halimeda $s p . s p .1(G)$. Turbinaria sp. sp.1

\subsection{Discussion}

Macroalgae U. fasciata, G. acerosa, Chaetomorpha sp., Halimeda sp., and Turbinaria sp. have various endophytic bacteria, consisting of gram-positive bacteria and gram-negative bacteria with different characteristics. Endophytic bacteria isolated from thallus in macroalgae.

Gram-positive bacteria have thick cell walls consisting of peptidoglycan and teicoic acid, so that the pores of gram-positive bacteria will close and keep the first dye complex as primary dye, namely crystal violet even when decolorizing or rinsing uses $96 \%$ alcohol. According to[12], gram-positive bacterial cell walls contain peptidoglycan, teicoic acid, and teicuronic acid. Therefore, the cell wall of gram-positive bacteria is composed of the majority of polysaccharides, whereas negative bacterial cell walls have only a small amount of peptidoglycan which is located between the outer membrane and the membrane in the cell wall. Gram negative bacteria have an outer cell wall consisting of a phospholipid component and several proteins also called auto layers.

According to, the cell wall of gram negative bacteria consists of 3 layers. The outermost layer is a lipoposaccharide (lipid) which is likely to be washed or decolorized by $96 \%$ alcohol as a decolorization agent, so that when stained with a second dye, air fuschin will be absorbed and become red. Gram negative bacteria look red because they contain higher amounts of lipids and fats when compared to gram-positive bacteria. In addition, according to ${ }^{[17]}$, gram negative bacteria have a lower or less peptidoglycan layer compared to gram-positive bacteria. This difference in the structure of bacterial cell walls causes the classification of bacteria into gram-positive or gram-negative bacteria. Based on the results of observations, it is evident that isolates of endophytic bacteria 2 belong to gram negative bacteria with a coccus or round shape.

The research found that Bacillus spp. wild type induced in growth in the Ulva fasciata thallus. According to[4] said that Bacillus spp. involved in the differentiation and growth of Ulva fasciata even in previous studies also mentioned that Bacillus spp. also influenced the morphology and growth of Ulva fasciata more than the growth of Ulva pertusa. So that it can be said that the bacteria of the genus Bacillus are more predominantly living in the macroalgae Ulvaceae.

Endophytic microfungi isolated from various types of macroalgae U. fasciata, $G$. acerosa, Chaetomorpha sp., Halimeda sp., and Turbinaria sp. consists of five genera which are thought to be Paecylomices sp., Mycelia sterilia, Geomyces pannorum, Penicillium sp., and Cladosporium sp. The five genera are mostly found as endophytic marine plants. Living marine endophytic microfungi colonize the internal tissues of host plants in a mutually beneficial manner and usually do not cause symptoms of obvious damage to the host plants they occupy. Endophytic microfungi have been proven to be a source of bioactive compounds from natural products with unique structures and high pharmaceutical activity. The interaction of endophytic microorganisms on host plants can occur symbiotic, that is, host plants will 
provide nutrients for endophytic growth, while endophytes will reward by producing substances that can provide protection that support the growth of their host plants[9].

Isolates obtained from Turbinaria sp. identified as Cladosporium sp. According to ${ }^{[18]}$ Cladosporium is an endophytic fungus isolated from macroalgae Sargasum sp. and Turbinaria sp. which were tested using UV spectrophotometer. Microfungi can tolerate relatively harsh environments and adapt to pressures heavier than most microorganisms. Halimeda sp. known to contain antimicrobial components and contain polyphenol components that play a role in inhibiting tumor development in animals[13].

From the results above shows that the macroalgae bacteria Gelidiella acerosa, Chaetomorpha sp., Halimeda sp., and Turbinaria sp. has antibacterial potential because it produces a zone of inhibition that appears as a clear area around the paper disk againts Escherichia coli bacteria. Although, the inhibition zone category is different. The largest inhibition zone is indicated by the macroalgae Halimeda sp. sp.1 with a zone of inhibition zone of $10.33 \mathrm{~mm}$ which is categorized as sensitive. The inhibition zone produced from endophytic bacteria is a sign that endophytic bacteria produce secondary metabolism as an antimicrobial compound. An antimicrobial compound can be known to inhibit or kill target microbes, including by disrupting cell metabolism, disrupting cell membrane permeability and can inhibit cell protein synthesis[14].

According to[15], states that the ability of bacterial isolates capable of inhibiting target microbial growth is a form of antagonistic activity carried out by these isolates by producing antimicrobial compounds. An active substance is said to have high potential as an antibacterial if at low concentrations it has a large inhibitory effect. Bacteria have different sensitivity levels where generally gram-positive bacteria are more vulnerable than gram-negative bacteria that are naturally more resistant. Important targets for antibiotics are bacteria, ribosomes, cell walls, cytoplasmic membranes, fat biosynthetic enzymes, and DNA replication and transcription[16].

Acknowledgements. this study has been completed properly and smoothly by the support of many stakeholders. therefore, we would like to thank all parties to the nature reserve and pangandaran nature tourism park in all forms of cooperation, direction and permission in conducting research in the region west beach pasir putih pananjung pangandaran, west java.

\section{References}

.[1] A. P. Kerswell, "Global biodiversity patterns of benthic marine algae," Ecology, 2006, doi: 10.1890/0012-9658(2006)87[2479:GBPOBM]2.0.CO;2.

[2] E. M. LALUPANDA, "KEANEKARAGAMAN MAKROALGA BERDASARKAN CIRI MORFOLOGI DI PANTAI WALAKIRI, KABUPATEN SUMBA TIMUR SEBAGAI SUMBER BELAJAR BIOLOGI,” 12 2015, 2015.

[3] S. A. Smith et al., "Bioactive endophytes warrant intensified exploration and conservation," PLoS One, 2008, doi: 10.1371/journal.pone.0003052.

[4] P. Habbu, V. Warad, R. Shastri, C. Savant, S. Madagundi, and P. Kekare, "In vitro and in vivo antimicrobial activity of ulva lactuca linn. (greer algae) associated endophytic bacterial Strains," J. Appl. Pharm. Sci., vol. 6, no. 10, pp. 138-146, 2016, doi: 10.7324/JAPS.2016.601019. 
[5] J. Zhao et al., "Endophytic fungi for producing bioactive compounds originally from their host plants," no. August 2015, pp. 567-576, 2010.

[6] M. Bahi, "Senyawa Antibiotika dari Bakteri dan Jamur Endofit: Mini review," Pros. Semirata FMIPA Univ. Lampung, 2013.

[7] S. Compant, B. Duffy, J. Nowak, C. Clément, and E. A. Barka, "Use of plant growth-promoting bacteria for biocontrol of plant diseases: Principles, mechanisms of action, and future prospects," Applied and Environmental Microbiology. 2005, doi: 10.1128/AEM.71.9.49514959.2005.

[8] P. Zhang, X. Li, and B. G. Wang, "Secondary Metabolites from the Marine Algal-Derived Endophytic Fungi: Chemical Diversity and Biological Activity," Planta Medica. 2016, doi: 10.1055/s-0042-103496.

[9] S. Larran, A. Perelló, M. R. Simón, and V. Moreno, "Isolation and analysis of endophytic microorganisms in wheat (Triticum aestivum L.) leaves," World J. Microbiol. Biotechnol., 2002, doi: 10.1023/A:1016857917950.

[10] M. Flora and W. T. L, "Microfungus Flora of Rice (Oryza sativa L.) and Wheat (Triticum durum L.) Grains from Corum Region (Turkey)," Int. J. Sci. Technol. Res., no. October, 2019, doi: $10.7176 /$ jstr/5-9-12.

[11] W. W. Davis and T. R. Stout, "Disc plate method of microbiological antibiotic assay," Appl. Microbiol., 1971.

[12] A. Helmiyati, "Pengaruh Konsentrasi Tawas Terhadap Pertumbuhan Bakteri Gram Positif Dan Negatif," J. Pangan dan Gizi, vol. 1, no. 1, pp. 1-6, 2010, doi: 10.26714/jpg.1.1.2010.

[13] I. Budi Setyawan, W. Prihanta, and E. Purwanti, "IDENTIFIKASI KEANEKARAGAMAN DAN POLA PENYEBARAN MAKROALGA DI DAERAH PASANG SURUT PANTAI PIDAKAN KABUPATEN PACITAN SEBAGAI SUMBER BELAJAR BIOLOGI," $J$. Pendidik. Biol. Indones., 2015, doi: 10.22219/jpbi.v1i1.2305.

[14] M. A. Kohanski, D. J. Dwyer, and J. J. Collins, "How antibiotics kill bacteria: From targets to networks," Nature Reviews Microbiology. 2010, doi: 10.1038/nrmicro2333.

[15] X. Xiao, P. Wang, X. Zeng, D. H. Bartlett, and F. Wang, "Shewanella psychrophila sp. nov. and Shewanella piezotolerans sp. nov., isolated from west Pacific deep-sea sediment," Int. J. Syst. Evol. Microbiol., 2007, doi: 10.1099/ijs.0.64500-0.

[16] E. Edition, "Brock Biology of Microorganisms," Cell, 2006. 
- $\quad$ E-mail address

- Full postal address (incl street name and number (location), city, postal code, state/province, country)

- $\quad$ Phone and facsimile numbers (incl country phone code)

$\mathrm{X}$

$\mathrm{X}$

$\mathrm{X}$

All necessary files have been uploaded, and contain:

\begin{tabular}{|l|l|}
\hline$\bullet$ Keywords & $\mathrm{X}$ \\
\hline$\bullet$ Running titles & $\mathrm{X}$ \\
\hline$\bullet$ All figure captions & $\mathrm{X}$ \\
\hline$\bullet$ All tables (incl title and note/description) & $\mathrm{X}$ \\
\hline
\end{tabular}

Further considerations

- Manuscript has been "spell \& grammar-checked" Better, if it is revised by a professional science editor or a native English speaker

- References are in the correct format for this journal

- All references mentioned in the Reference list are cited in the text, and vice versa

- Colored figures are only used if the information in the text may be losing without those images

- Charts (graphs and diagrams) are drawn in black and white images; use shading to differentiate 